Andrii P. Tyshchenko, Pavlo M. Kuzmenko, Serhiy A. Vyzva

Taras Shevchenko National University of Kyiv, National Joint-Stock Company Naftogaz of Ukraine Subsidiary Enterprise Scientific Research Institute of the Oil and Gas Industry

Stanislav O. Sklyarov, Tetiana M. Kuzmenko

National Joint-Stock Company Naftogaz of Ukraine Subsidiary Enterprise Scientific Research Institute of the Oil and Gas Industry

\title{
A new algorithm of migration velocity computation and testing in a complex geological area
}

\begin{abstract}
This paper is devoted to the investigation of 3D seismic imaging experience in complex geological conditions of the Kerch shelf of the Black Sea. Special attention is paid to the new author's algorithm for migration velocity computation. The main problems of migration velocities computation are described. The signal "time stretching" is absent, which is present after a manual analysis. The implemented algorithm for migration velocity analysis and computation is both independent from subjective human factor and fast. The optimal fast migration algorithm for seismic data of the complex geological area in the Ukrainian part of the Black Sea is the Kirchhoff algorithm. Its efficiency with real results demonstration is shown.

Aim of work: Create a special technique for migration velocity computation with respect to the Kerch shelf. Approve the velocity in optimal fast migration algorithm for seismic data in complex geological conditions.

New aspects covered: Author's algorithm for Migration Velocity computation is developed. The migration velocity is approved in optimal fast imaging algorithm for seismic data in complex geological conditions.
\end{abstract}

Key words: seismic processing, migration velocity, velocity analysis, Kerch shelf, Kavkazska area.

\section{Nowy algorytm obliczeń prędkości propagacji i badania w złożonym obszarze geologicznym}

Ten artykuł jest poświęcony badaniom w zakresie obrazowania sejsmicznego 3D w złożonych warunkach geologicznych szelfu krymskiego (okolice Kerczu) nad Morzem Czarnym, ze szczególnym uwzględnieniem nowego autorskiego algorytmu obliczania prędkości propagacji. Opisano główne problemy w związku z obliczeniami prędkości propagacji. Sygnał time stretching (zmiana czasu trwania) jest nieobecny, lecz pojawia się po analizie manualnej. Wprowadzony algorytm do analizy prędkości propagacji i obliczeń jest niezależny od subiektywnego czynnika ludzkiego i szybki. Optymalnym algorytmem dla propagacji fal o dużej prędkości i danych sejsmicznych obejmujących geologiczny obszar w ukraińskiej części Morza Czarnego jest algorytm Kirchhoffa. Badania wykazały wysoki stopień skuteczności tego algorytmu.

Cel pracy: Wypracować specjalną technikę obliczania prędkości propagacji w odniesieniu do szelfu krymskiego (okolice Kerczu). Przyjęto prędkość w algorytmie optymalnie szybkiej propagacji fal dla danych sejsmicznych w złożonych warunkach geologicznych.

Innowacja: Opracowano autorski algorytm dla obliczeń prędkości propagacji fal. Przyjęto prędkość propagacji w algorytmie optymalnie szybkiego obrazowania dla danych sejsmicznych w złożonych warunkach geologicznych.

Słowa kluczowe: przetwarzanie sejsmiczne, prędkość propagacji, analiza prędkości, szelf krymski, obszar Kaukazu.

\section{Introduction}

Deviation from a true geological section during a seismic imaging process, increases with increasing both angles of reflections and migration velocity errors. In state-of-the-art processing systems there are many algorithms for implementation 
of seismic imaging. They make it possible to execute time and depth migration, both on input pre-stack and post-stack data. In this case, different algorithms are not equally responsive to the dip angle changes of reflecting boundaries, to lateral and vertical velocity gradient, to different frequency characteristics of the wave field, to level of signal-to-noise ratio and accuracy of velocity model data, especially when complex geology is present. Therefore, there are definite challenges for both migration velocities and optimal migration transformation algorithm, that satisfy quality conditions of migrated seismic data from the reliability formation point of sedimentary rocks of complex geological models in the Black Sea.

\section{Migration Velocity computation for complex geological conditions}

In complex geological conditions the dip angle of the reflecting surface has a huge influence on spatial hodograph as shown in Figure 1. For example, in Figure 1a is shown, a synthetic hodograph for VTI media models with angles of the reflection surface $\alpha=0^{\circ}, \beta=0^{\circ}$ and looks like a hyperboloid. In this case CDP velocities determination is simple, but when the reflecting surface has a dip angle, $\alpha=40^{\circ}, \beta=0^{\circ}$ (Figure 1b) then the hodograph is a complex hyperboloid parabolic hyperboloid. And in the case which is shown in Figure $1 \mathrm{c}$ when the reflection surface has two angles component, $\alpha=40^{\circ}, \beta=20^{\circ}$, the form of the hodograph is very complex. In the last two cases ( $1 \mathrm{~b}$ and $1 \mathrm{c}$ ), an accurate manual velocity determination is impossible. Hence the conclusion that for velocity analysis the adaptive algorithm as shown by Gorbunov, Sklyarov (2006) should be applied. The results of velocity computation are both independent from subjective human factor and fast.

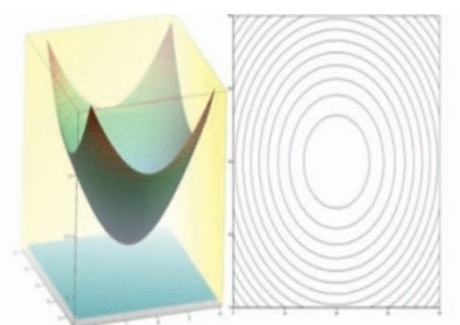

a) $\alpha=0^{\circ}, \beta=0^{\circ}$

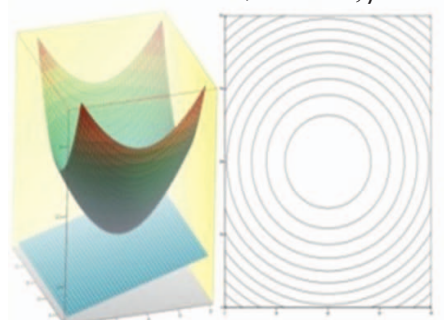

b) $\alpha=40^{\circ}, \beta=0^{\circ}$

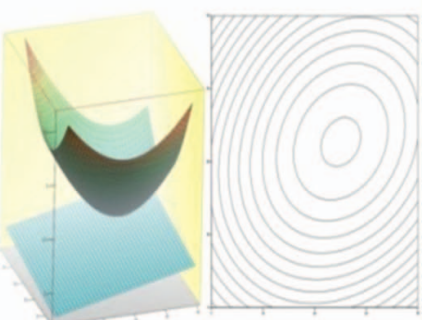

c) $\alpha=40^{\circ}, \beta=20^{\circ}$
Fig. 1. Spatial hodograph CDP

Migration Velocity is determined with the author's algorithm application [2]. Algorithm of velocity analysis can be realized in another way. Signal samples are stacked with constant time delay $-t_{0}$, which are controlled by the hodograph curvature (window of constant curvature). Selected information is divided into time intervals such as a "sliding" window as shown in Figure 2. This manipulation forms a stack trace. The next step is performing a statistical analysis of the combined stacked traces, with regular waves determination and the curvature parameter definition at a registration time. As a result the effective velocity and resulting signal are formed. The formed set of values is inserted into the procedure, of the reliability statistical estimation, of the existence for a regular wave field component determination using coherent wave criteria. The wave must be determined by given kinematic characteristics (it is similar to the procedure for maximum amplitudes determination on the stacked section of the controlled directional receiving method).

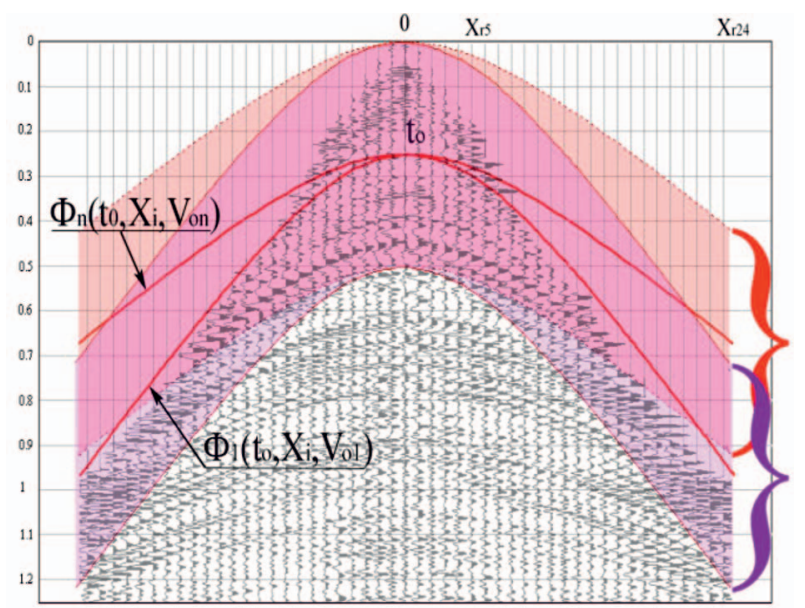

Fig. 2. The set of delay functions in time windows

Because a time lag function within a constant window curvature has no changes, the computation speed is substantially increasing in relation to the conventional CDP "velocity analysis". Besides that, the signal "time stretching" disappears, which is present after a manual analysis.

It is clear that the effective CDP velocity values defined by the "real" hyperbolic hodograph shape of the reflected wave and function of time delay, should be constant in time. These values should be so close, so that their differences will not affect the result of the interference wave selection, during the process of signals stacking. Therefore, when determining the value it should be selected in such way, that the mentioned differences should be optimal, as shown below: 


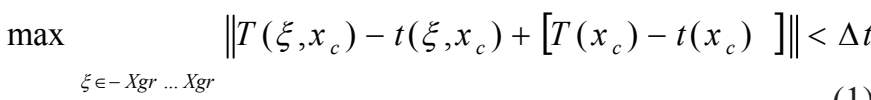

$\Delta t$-admissible shift between time lags.

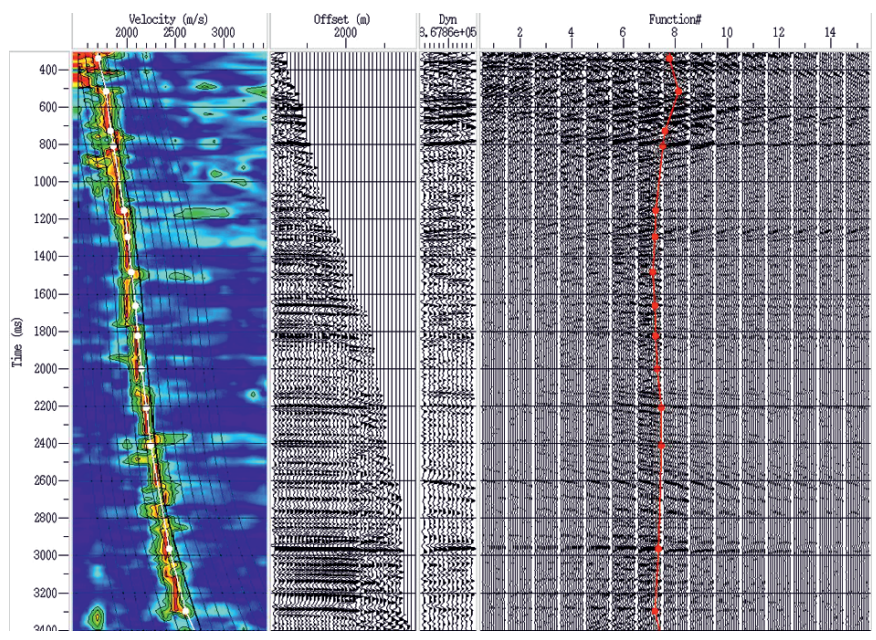

Fig. 3. Vertical time spectrum of stacking velocities
In Figure 3 vertical time spectrum of stacking velocities is shown. We can see the accurate velocity determination without any NMO stretching. Fragment of stacking velocities is presented in Figure 4.

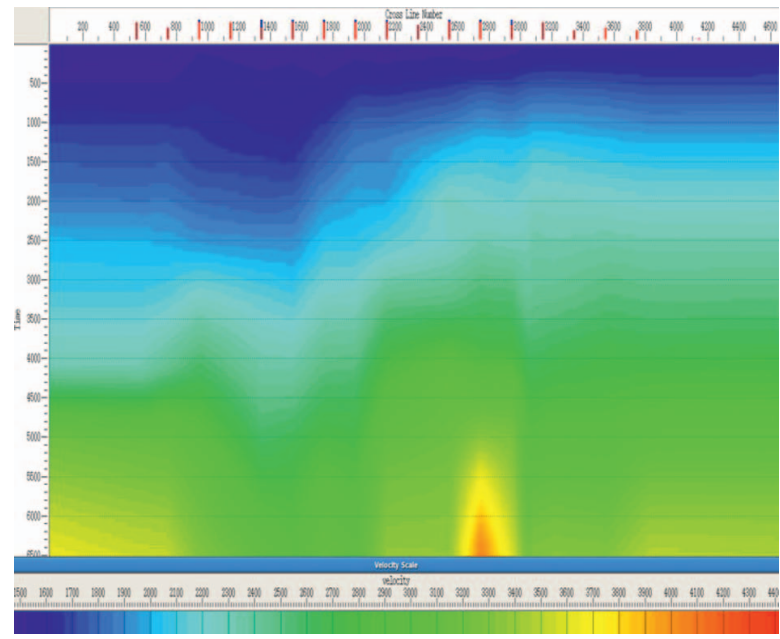

Fig. 4. Time section fragment of stacking velocities

\section{Seismic data migration algorithms testing for the complex geology of the Kavkazka area}

Kavkazska area is presented in this work as a practical example. The area is located within the Ukrainian part of the Kerch shelf. A 3D survey area is located in the south-eastern part of the Kerch-Taman depression. The Kavkazska area is located $30 \mathrm{~km}$ south of the Crimean peninsula, its sea level variations are from $50 \mathrm{~m}$ to $400 \mathrm{~m}$.

The derived migration velocities are used as the base for further correction of migration transformation procedure parameters. Relatively fast migration transforming procedure was used at the testing stage. This procedure is called a phase shift migration. It is based on the Gazdaga approximation [1] and it recalculates the input data into the lower half-space, which is equivalent to a phase shift in the FK space.

Stepwise, extrapolation of the wave field into the lower half-space occurs in a form that reproduces the shift down the surface of observation, using a scalar wave equation. This migration takes into account the vertical variation of speed and provides a display of items with angles of up to 90 degrees, but lateral velocity should change gradually. The importance of this procedure's application is the availability of relatively fast implementation of this algorithm in the processing system. This allows rapid testing of required parameters with satisfactory accuracy of the account of the seismic displacement. Conversion of migration velocity values to interval migration velocity, is done by specialized procedures in processing systems using smoothed gradient algorithm.

Testing and further execution of the ultimate 3D Post Stack migration procedure, was based on the Kirchhoff equation [3], where the integration is performed using such elements of an unmigrated area that form one element in a migrated area. Namely, there are implemented stacking using diffraction curve at each point of the unmigrated section and getting amplitude values at each point in the migrated section. In other words, if the energy comes from a point at the top of the diffraction curve, then the stacking along such a curve, returns a value that corresponds to the energy obtained at that point. When the simulated hodograph of diffracted waves coincides with the registered hodograph, the stacked traces values are high. In other cases, the amplitude values are much lower. Migration software that uses this method includes vertical velocity variations and reflection angles up to 90 degrees, with better accounting for lateral velocity variations than by the previous procedure of phase shift migration. However, the calculation time of the Kirchhoff migration process, is greater than that for the same phase shift procedure. Therefore Kirchhoff migration is used only at the final processing stage.

In Figure 5 a fragment of the unmigrated time section is demonstrated. The seismic wave field is very complex and characterized by step dip reflectors. In this case a correct velocity model must be provided. The $3 \mathrm{D}$ velocity volume for migration is shown in Figure 6.

To demonstrate the results there are a series of comparative sections (see Figure 7-10) of vertical and horizontal cube slices after the Post Stack Time Migration transformation. Figures 7-8 show the comparison of the time sections before and after the migration. Figures 9-10 demonstrate 
the horizontal slices of unmigrated and migrated cubes at a time of $4000 \mathrm{~ms}$. Analyzing the migrated sections, we can say that their quality is satisfactory for clear and convincing interpretation in most cases.

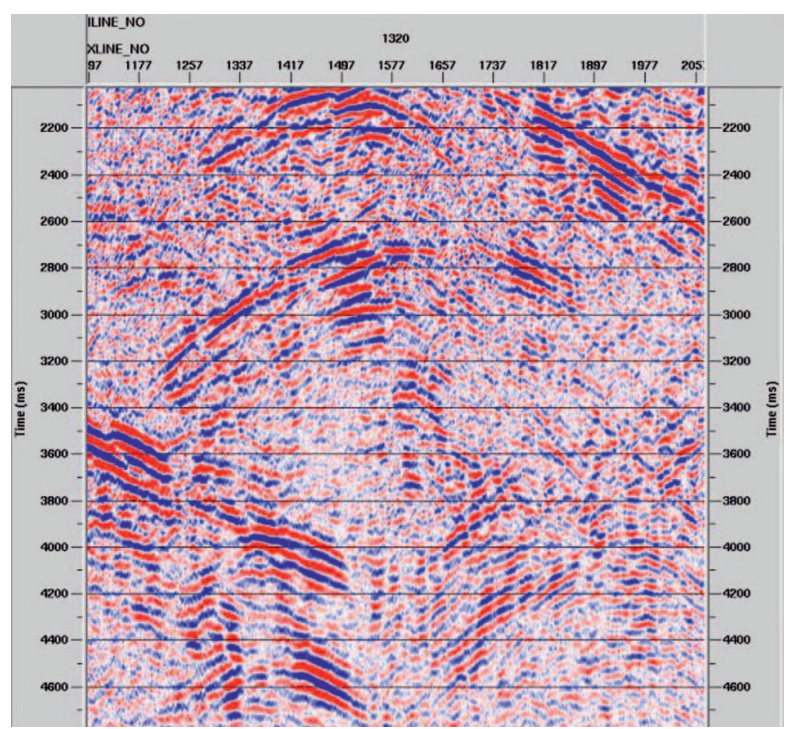

Fig. 5. Fragment of unmigrated section

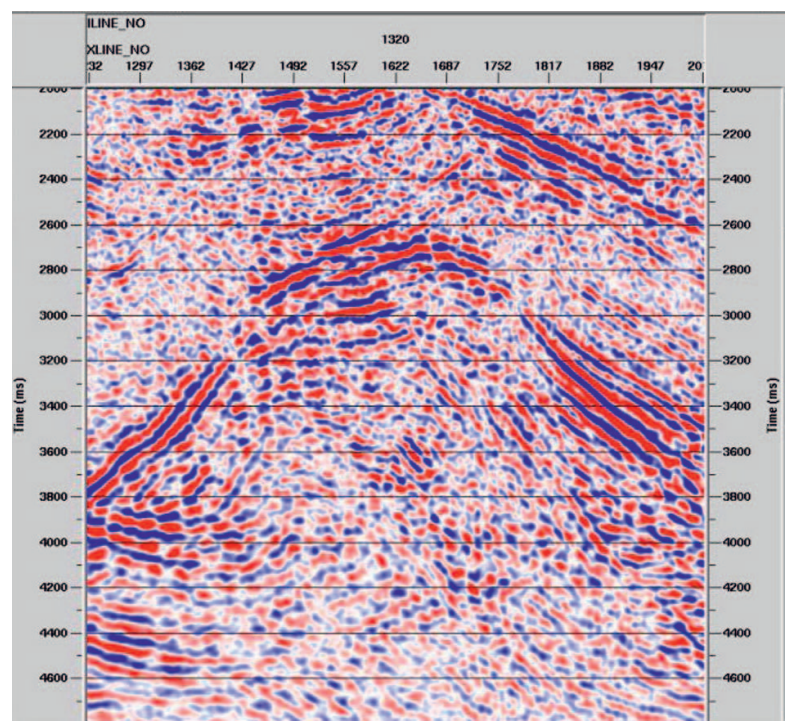

Fig. 7. Fast Phase Shift migration algorithm

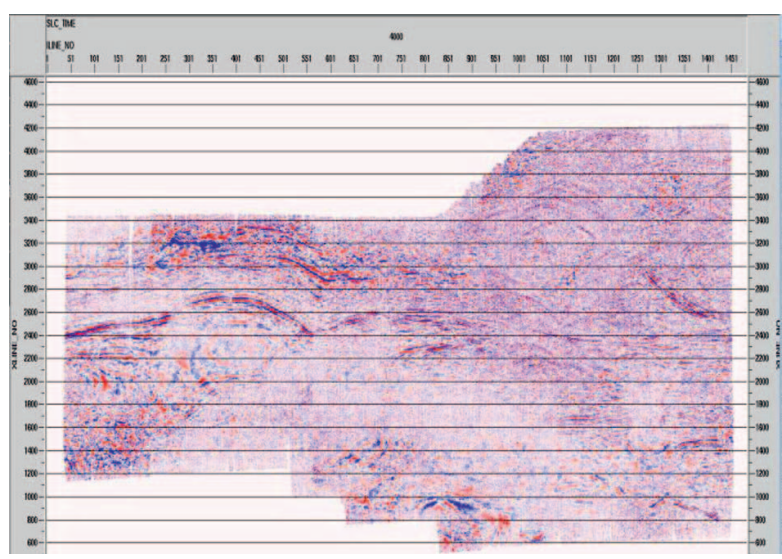

Fig. 9. Slice -4000 . Time slice fragment of seismic cube before migration procedures application
Using such materials we can confidently allocate certain geometric shapes in the structure of the sedimentary layers, creating favorable conditions for the possible allocation of hydrocarbon traps.

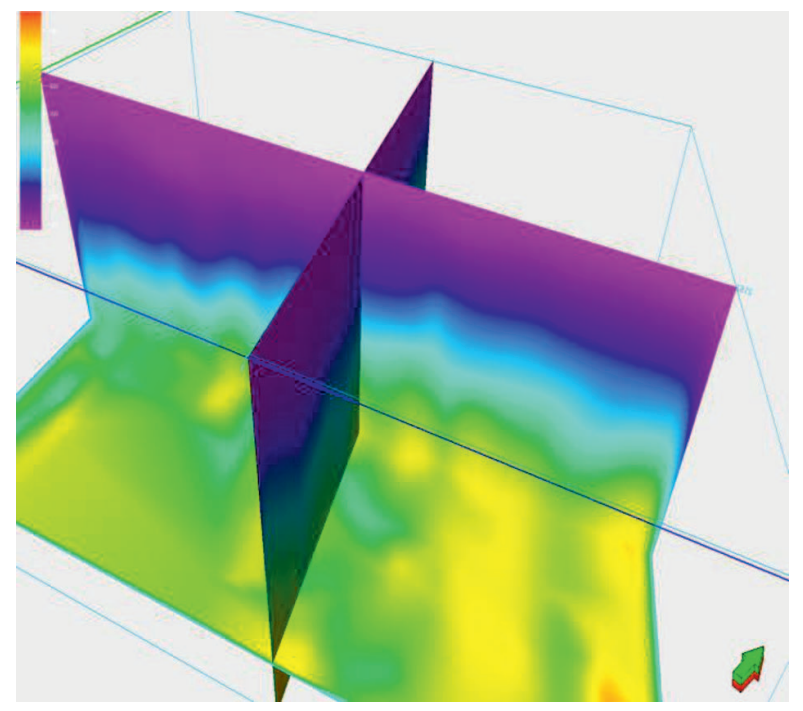

Fig. 6. Migration velocity volume

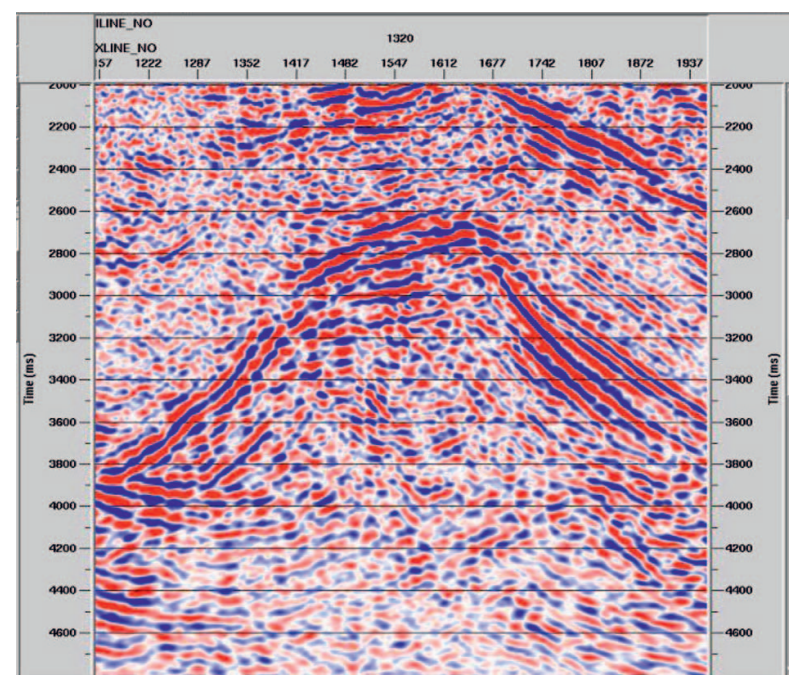

Fig. 8. Kirchhoff migration algorithm

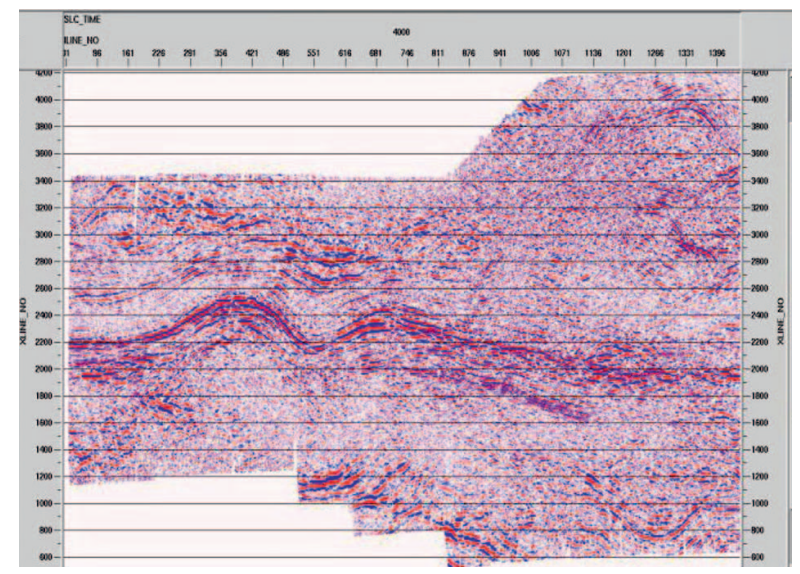

Fig. 10. Slice -4000 . Time slice fragment of seismic cube after Kirchhoff migration procedure 


\section{Conclusion}

Implemented algorithm for migration velocity analysis and computation is both independent from subjective human factor and fast. The signal "time stretching" is absent, which is present after a manual analysis. Analyzing obtained migration results, we can say that all the above migration algorithms work well enough. They eliminate the diffracted waves (incoherent noise component of the seismic wave field). It is advisable to use a Phase Shift algorithm for rapid assessment of the velocity model, which is usable for migration procedures if there are no wide angles of reflecting boundaries. This algorithm requires less computer time and gives a fairly acceptable result for a visual assessment of the source data. Optimal fast migration algorithm for seismic data of the complex Kavkazska area, is the Post-Stack Kirchhoff algorithm. Good quality of seismic imaging and short computer execution time justifies the working efficiency.

\section{Acknowledgements}

The authors are very grateful to all their colleagues at NJC "Naftogas of Ukraine" SE "Naukanaftogaz" who were involved in the research work and discussions.

Please cite as: Nafta-Gaz 2016, no. 3, pp. 164-168, DOI: 10.18668/NG.2016.03.02

Article contributed to the Editor 9.11.2015. Approved for publication 21.01.2016.

\section{Literature}

[1] Gazdag J., Sguazzero P.: Migration of seismic data by phaseshift plus interpolation. Geophysics 1984, vol. 49, pp. 124-131.

[2] Sklyarov S.O.: Seismic dynamic images with author algorithm based on modified regulated directional analysis. Problems of oil and gas industry. Coll. science works, Kyiv, 2011, issue 9, pp. 159-164.

[3] Yilmaz Ö.: Seismic data analysis. Society of Exploration Geophysicists 2001. http://dx.doi.org/10.1190/1.9781560801580.

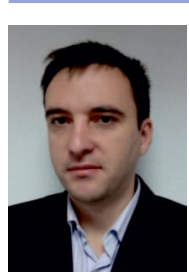

Pavlo KUZMENKO

associate professor, geoscientist

Taras Shevchenko National University of Kyiv, National Joint-Stock Company Naftogaz of Ukraine Subsidiary Enterprise Scientific Research Institute of Oil and Gas Industry

Vasilkivska 90 str, Kyiv

E-mail:pavlokn@ukr.net

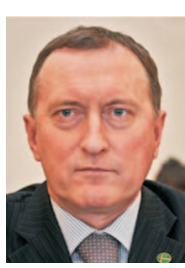

Serhiy Andriyovych VYZHVA

Professor, Doctor of Geology, Head of the

Department of Geophysics

Taras Shevchenko National University of Kyiv

64/13, Volodymyrska Street, City of Kyiv,

Ukraine, 01601

E-mail:vyzhva_s@ukr.net

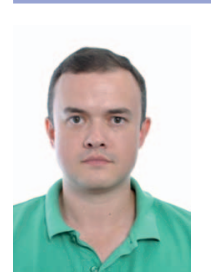

Andrii TYSHCHENKO

associate professor, geoscientist

Taras Shevchenko National University of Kyiv, National Joint-Stock Company Naftogaz of Ukraine Subsidiary Enterprise Scientific Research Institute of Oil and Gas Industry Vasilkivska 90 str, Kyiv

E-mail: aptyshchenko@gmail.com

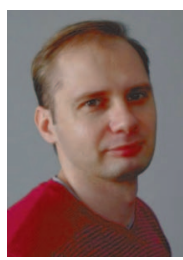

Stanislav SKLYAROV

geoscientist

National Joint-Stock Company Naftogaz of Ukraine Subsidiary Enterprise Scientific Research Institute of Oil and Gas Industry

8 Kyivska str., Vyshneve city, Kyiv-Sviatoshyn district, Kyiv, 08132, Ukraine

E-mail:sklyarov@naukanaftogaz.net

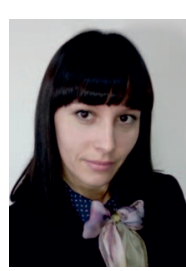

Tetiana KUZMENKO

Researcher of Department of oil and gas fields development systems

National Joint-Stock Company Naftogaz of Ukraine Subsidiary Enterprise Scientific Research Institute of Oil and Gas Industry

8 Kyivska str., Vyshneve city, Kyiv-Sviatoshyn district, Kyiv, 08132, Ukraine

E-mail:kuzmenko_tm@ukr.net 